\title{
Actions to prevent sexual violence against adolescents: an integrative literature review
}

\author{
Acciones para prevenir la violencia sexual contra los adolescentes: Revisión integradora de la literatura \\ Acciones para prevenir la violencia sexual contra los adolescentes: revisión integradora de la literatura
}

\section{Alejandra Isabel Vargas Rivera ORCID: 0000-0003-3575-9757 \\ Edna Johana Mondragón-Sánchez ${ }^{1,1}$ ORCID: 0000-0002-7950-2809 \\ Fatima Karine Apolonio Vasconcelos ORCID: 0000-0001-8022-6840 \\ Patricia Neyva da Costa Pinheiro' ORCID: 0000-0001-7022-8391 \\ Adriana Gomes Nogueira Ferreira"I ORCID: 0000-0002-7107-1151 \\ Marli Teresinha Gimeniz Galvão' ORCID: 0000-0003-3995-9107}

' Universidade Federal do Ceará. Fortaleza, Ceará, Brazil. "Universidade do Quindio. Armênia, Quindio, Colômbia.

II' Universidade Federal do Maranhão, Imperatriz, Maranhão, Brazil.

How to cite this article:

Rivera AIV, Mondragón-Sánchez EJ, Vasconcelos FKA, Pinheiro PNC, Ferreira AGN, Galvão MTG. Actions to prevent sexual violence against adolescents: an integrative literature review. Rev Bras Enferm. 2021;74(Suppl 4):e20190876.

doi: http://dx.doi.org/10.1590/0034-7167-2019-0876

\section{Corresponding author:}

Edna Johana Mondragón Sánchez E-mail: ejmondragon@uniquindio.edu.co

EDITOR IN CHIEF: Antonio José de Almeida Filho ASSOCIATE EDITOR: Priscilla Broca

Submission: $04-28-2020$

Approval: $10-06-2020$

\begin{abstract}
Objective: to identify actions to prevent adolescent sexual violence. Method: an integrative literature review of five databases, Medline/Pubmed, Scopus, Lilacs, Bdenf, Cinahl using the following descriptors "adolescent" "adolescence" "youth" "primary prevention" "prevention" "primary" "sexual violence", plus the Boolean operators AND and OR, with a final sample of 24 articles; the evidence was assessed by the Grading of Recommendations Assessment, Development and Evaluation Results: the review identifies different structures of the study object, classified in the categories "Interventions with programs created by authors" and "Interventions with standard programs". Conclusion: there are actions to prevent sexual violence against adolescents; the participants' knowledge was assessed immediately after the intervention, but the assessment of the participants' acquisition of habits and behavioral changes was to a lesser extent; health prevention is crucial for society's healthy development, which demonstrates that its applicability in the environment directly favors human health. Descriptors: Adolescent; Primary Prevention; Sex Offenses; Nursing; Health Education.
\end{abstract}

\section{RESUMEN}

Objetivo: Identificar acciones de promoción de la salud para prevenir la violencia sexual de adolescentes. Método: Revisión integrativa de la literatura de cinco bases de datos de Medline/Pubmed, Scopus, Lilacs, Bdenf, Cinahl con descriptores "adolescente" "'adolescence" "youth" "primary prevention" prevention" "primary" "sexual violence" utilizando operadores booleanos AND y OR, con una muestra final de 24 artículos Grading of Recommendations Assessment, Development and Evaluation. Resultados: La revisión identifica diferentes estructuras del objeto de estudio, clasificadas en las categorías 'Intervenciones con programas desarrollados por los autores" e 'Intervenciones con programas para padres" Conclusión Existen medidas para prevenir la violencia sexual en adolescentes; el conocimiento de dos participantes fue medido inmediatamente después de la intervención, pero la medición de la adquisición de hábitos y cambios de comportamiento de los participantes fue menor; la prevención de la salud es fundamental para el desarrollo saludable de la sociedad, lo que demuestra que su aplicabilidad en el medio, favorece directamente la salud humana. Descriptores: Adolescente; Prevención Primaria; Delitos Sexuales; Enfermería; Educación en Salud.

\section{RESUMO}

Objetivo: identificar ações de promoção da saúde para prevenir a violência sexual de adolescentes. Método: revisão integrativa da literatura de cinco bases de dados Medline/ Pubmed, Scopus, Lilacs, Bdenf, Cinahl com descritores"adolescent"''adolescence"'"youth" "primary prevention"'"prevention"' primary" "sexual violence" usando operadores booleanos AND e OR, com amostra final de 24 artigos; a evidência foi avaliado pelo Grading of Recommendations Assessment, Development and Evaluation. Resultados: a revisão identifica diferentes estruturas do objeto de estudo, classificadas nas categorias "Intervenções com programas criados por autores " e "Intervenções com programas padrão". Conclusão: existem ações para prevenir a violência sexual de adolescentes; o conhecimento dos participantes foi medido imediatamente após a intervenção, mas a mensuração da aquisição de hábitos e mudanças comportamentais dos participantes foi menor; a prevenção da saúde é essencial para o desenvolvimento saudável da sociedade, o que demonstra que sua aplicabilidade no ambiente favorece diretamente a saúde humana.

Descritores: Adolescente; Prevenção Primaria, Delitos Sexuais; Enfermagem; Educação em Saúde. 


\section{INTRODUCTION}

Sexual violence is one of the global problems that affect all types of society, being a social problem throughout the world. Sexual violence against adolescents is one of the most perverse forms of violence because it is characterized by the use of sexuality in this population, to violate their sexual rights and privacy.

The World Health Organization (2017) ${ }^{(1)}$ warns that $35 \%$ of women worldwide have gone through sexual violence from their relatives, family members or strangers at least once. Considering that only $5 \%$ of sexually assaulted women report that, this is an unbearable situation in the global scenario, further aggravated in some countries.

In Latin America and the Caribbean countries, the rates of sexual violence vary from $5 \%$ to $15 \%$. According to the Observatorio de Seguridad Ciudadana de la Organización de Estados Americanos (OEA) (Citizen Security Observatory of the Organization of American States), the countries with the highest cases of sexual violence in South America are Bolivia, Peru and Brazil, respectively ${ }^{(1)}$.

In Bolivia in January 2019, the percentage of women (87 \%) is higher than the same period of the previous year ( $85 \%)$, while the percentage of men (13\%) is lower than the same period of the previous year (15\%). In Peru, $76 \%$ of rape victims are underage, according to a study by the Programa de Investigación e Investigación Criminal del Ministerio Público (Criminal Investigation and the Public Ministry Investigation Program, which covers from 2013-2017(1).

As shown in the Brazilian Public Security Forum in 2016 (FBSP) (2), a person experiences some type of sexual violence in Brazil every 12 minutes and, according to the reported cases, it was observed that in 2015 there were 45,460 cases of rape reported to the authorities, representing a decrease of $9.9 \%$ (45,920 cases) compared to the 2014 data. However, the FBSP warned that "it is not possible to affirm that there was a decrease in rapes in Brazil" because most cases are not reported to the authorities.

The Leavell and Clark Model (1976) describes prevention as early action, based on knowledge of the disease's natural history to make unlikely progress; furthermore, it is a set of actions aimed at preventing disease in the population, eliminating causal factors, that is, aiming at reducing the incidence of the disease.

Therefore, these prevention actions during the community empowerment process are also directed at specific audiences due to their vulnerability, for example, the adolescent population. This population is in a stage of growth, learning and curiosity, which leads them to risky actions to get to know their environment ${ }^{(3)}$.

Violence is one of these risks; sexual assaults make up a substantial percentage in young people; authors suggest that, of the total number of women treated in an emergency care center for cases of sexual assault, 3.2\% of the cases were adolescents ${ }^{(4)}$. The antecedents are supported by the Instituto Nacional de Medicina Legaly Ciencias Forenses de Colombia (Colombia's National Institute of Legal Medicine and Forensic Sciences), which shows that $70.6 \%$ of the rate of sexual abuse are people under 18 years of age. Of this percentage, the age range from 10 to 14 years presented a rate of 103.6 per 100.000 and from 15 to 17 years of 67.4 per $100.000^{(5-6)}$.

The aforementioned data show a reality: the difficulty of facing sexual violence, particularly in adolescence. Health professionals, educators, parents, among others, are often involved amid a lack of knowledge of the magnitude of the problem and the matter, as well as the impact on society, families and the adolescents' ${ }^{\prime}$ ives ${ }^{(3-6)}$. Given the above, a reality that must be alleviated or lessened by different social actors is shown. However, these protagonists are influenced by unknowing the problem's magnitude, the impact on society, the family and adolescence, which results in a decrease in education for the prevention of sexual violence ${ }^{(3)}$.

Given this scenario, it is crucial to know what work is being done worldwide to address this gap in preventing adolescent sexual violence. Therefore, the following question was established: What are the actions to prevent sexual violence in adolescence?

\section{OBJECTIVE}

To identify actions to prevent sexual violence in adolescence.

\section{METHODS}

\section{Type of study}

This is an integrative literature review ${ }^{(7)}$. This method allows for analysis of the existing literature, providing a comprehensive understanding of a particular object of study. It can be applied in several topics and/or study designs, contributing to the practice of nursing based on scientific evidence. It provides an increase in evidence-based practice, which enables us to search, collect, categorize, evaluate and synthesize the results investigated, focusing on the prevention of sexual violence in adolescence ${ }^{(7)}$.

\section{Methodological procedures}

For the elaboration of this study, the following steps were followed: formulation of the problem and research question along with the elaboration of the review protocol, protocol approval, data collection, data analysis and interpretation, organization of data in categories and presentation of results and conclusions ${ }^{(7)}$.

\section{Data collection and organization}

First step: The establishment of the structured research question in the PICoT acronym format ${ }^{(8)}$. In this first stage, the theme related to health prevention was chosen, since it is the basis of the Nursing graduate program; health education because it is the research line of researchers; adolescents, because researchers work with this population and the sexual violence issue. The question was structured in the following way: $P=$ Population, adolescents; $I=$ Interest, strategies to prevent sexual violence; $\mathrm{C}=$ Context, $\mathrm{WHO}$ and UNICEF; and T=Time was not an object of study ${ }^{(9-10)}$. The topic was related to the prevention of sexual violence.

Second stage: establishment of criteria for the inclusion and exclusion of studies/sampling or bibliographic search. The second stage was carried out in April 2019 in the databases: Pub/Medline (National Library of Medicine and National Institutes of Health) and SCOPUS, as they are specific international databases for the health field; LILACS (Latin American and Caribbean Literature in Health Sciences), included because it is the region where the researcher's countries are located and because it is from the health field; CINAHL (The Cumulative Index to Nursing and Allied Health 
Literature), specific base in the field of Nursing with international scope and BDENF (Nursing Database) a Brazilian nursing base, using the following descriptors and keywords: adolescent, sex offenses, primary prevention, youth, adolescence, prevention and primary. Combinations were made between the descriptors and/or keywords that originated the search strategies described in Chart 1.

Chart 1 - Search strategies

\begin{tabular}{|c|c|}
\hline $\begin{array}{l}\text { MEDLINE/ } \\
\text { PUBMED }\end{array}$ & $\begin{array}{l}\text { ("adolescent" [MeSH Terms] ("adolescent" AND "sexual } \\
\text { violence" AND"primary prevention","adolescent" OR"sexual } \\
\text { violence" OR "primary prevention","adolescent" AND } \\
\text { "sexual violence" OR"primary prevention","adolescent" OR } \\
\text { "sexual violence" AND "primary prevention AND (English } \\
\text { [lang] OR Portuguese [lang] OR Spanish [lang]) }\end{array}$ \\
\hline SCOPUS & $\begin{array}{l}\text { (TITLE-ABS-KEY ("adolescent" AND "sexual violence" AND } \\
\text { "primary prevention","adolescent" OR "sexual violence" OR } \\
\text { "primary prevention","“adolescent" AND "sexual violence" } \\
\text { OR "primary prevention"," "adolescent" OR "sexual violence" } \\
\text { AND "primary prevention) }\end{array}$ \\
\hline $\begin{array}{l}\text { LILACS e } \\
\text { BDENF }\end{array}$ & $\begin{array}{l}\text { (tw: ("adolescent" AND "sexual violence" AND "primary } \\
\text { prevention","'adolescent" OR"sexual violence" OR "primary } \\
\text { prevention","'adolescent" AND "sexual violence" OR "primary } \\
\text { prevention","'adolescent" OR "sexual violence" AND } \\
\text { "primary prevention") AND (db: ("LILACS" OR "BDENF"). }\end{array}$ \\
\hline CINAHL & $\begin{array}{l}\text { ("adolescent" AND "sexual violence" AND "primary } \\
\text { prevention","adolescent" OR "sexual violence" OR "primary } \\
\text { prevention", "adolescent" AND"sexual violence" OR } \\
\text { "primary prevention"," "adolescent" OR "sexual violence" } \\
\text { AND "primary prevention) }\end{array}$ \\
\hline
\end{tabular}

\section{Data analysis}

From the data collection, 801 studies that underwent the first stage of the evaluation were found after applying the inclusion and exclusion criteria previously defined in the research protocol.

Inclusion criteria: full-text research articles, available online, in English, Spanish and Portuguese; articles that have adolescents as a population, according to the criteria set by the World Health Organization (2000), which define as the stage of the person from 10 to 19 years.

Exclusion criteria: editorials, reviews, experience reports, theoretical reflections, dissertations, theses, and monographs; abstracts published at events. Doubled articles that were not directly related to the theme and those that did not have a clear methodology concerning the interventions developed and which confused the research process were also excluded.

Articles that were in more than one database were considered duplicates and were automatically removed. Therefore, a sample of 182 studies was obtained at the end of the first stage of the article evaluation, of which 68 (37.36\%) in Medline/Pubmed, 84 (46.15\%) in SCOPUS, 3 (1.64\%) were found in LILACS, 1 (0.54\%) in BDENF and 14 (14.28\%) in CINAHL.

In the second stage, the 182 articles were read in full to identify those that answered satisfactorily to the research question and/ or were relevant for the study. From this process, a sample of 24 included articles was obtained, 8 (33.33\%) from Medline/Pubmed, 11 (45.83\%) from SCOPUS, none from LILACS, none from BDENF and 5 (20\%) from CINAHL. The flow chart detailing the steps of the investigation is presented in Figure 1. The quality of the set of evidence and the strength of the recommendation were assessed using the Grading of Recommendations Assessment, Development and Evaluation (GRADE) tool(11-12).

For the data extraction from the articles, it is necessary to evaluate the eligibility of the papers presented by the databases. For that, a screening of the articles was prepared by reading the title and abstract to apply the inclusion and exclusion criteria of the study. After this first screening, we proceeded to a detailed reading of the articles that were examined. The end of this stage consisted of the organization and synthesis of the collected data, which are recorded in a summary table containing the identification author/year; article title; the objective, methodology used; main results; researcher observations and/or significant excerpts highlighted in the article.

\begin{tabular}{|c|c|c|c|c|}
\hline \multicolumn{5}{|c|}{ Search Strategy } \\
\hline \multicolumn{5}{|c|}{ Data collection } \\
\hline \multicolumn{5}{|c|}{ Total of 801 items found } \\
\hline Medline/Pubmed & SCOPUS & LILACS & BDENF & CINAHL \\
\hline 354 & 371 & 15 & 3 & 58 \\
\hline & & & \multicolumn{2}{|c|}{$\begin{array}{l}\text { Applied inclusion or } \\
\text { exclusion criteria }\end{array}$} \\
\hline
\end{tabular}

\begin{tabular}{|c|c|c|c|c|c|}
\hline & 1 st \\
182 items & Medline/Pubmed & SCOPUS & LILACS & BDENF & CINAHL \\
\cline { 2 - 6 } & 68 & 84 & 3 & 1 & 26 \\
\hline
\end{tabular}

What are the actions to prevent sexual violence in adolescence?

\begin{tabular}{|l|c|c|c|c|c|}
\hline $\begin{array}{l}2^{\text {nd }} \text { Stage } \\
24 \text { items }\end{array}$ & Medline/Pubmed & SCOPUS & LILACS & BDENF & CINAHL \\
\cline { 2 - 6 } & 8 & 11 & 0 & 0 & 5 \\
\hline
\end{tabular}

Figure 1 - Data collection and analysis flow diagram

\section{RESULTS}

The results begin with a description of the characteristics of the 31 articles ${ }^{(13-36)}$ included in this review (Chart 2). In the analysis full-text, "Cochrane handbooks for Systematic Review" (2011) were used, since it advises to present coding of the characteristics of specific studies that can be categorized into groups that correspond to the information needed in the study ${ }^{(14)}$, and they coded studies according to interventions, including: who gave the intervention, content, format, time, educational technique presented.

The articles presented four levels of evidence. Level 4, eight articles with descriptive observational studies; level 3, an article with analytical observation; level 2, quasi-experimental with seven articles; and level 1: experimental 1a, five articles with systematic reviews of controlled studies; and $1 \mathrm{~b}$, three articles with systematic reviews of controlled studies.

In the end, we worked with 24 selected articles, which were read completely. Their main information was organized in individual brief tables with the title of the article, year of identification of the authors, objectives/hypotheses, type of study, sample size, type of educational intervention, the author who developed the educational action. This way of organizing the data provided a more didactic visualization of the information, enabling the articles' categorization. 
Chart 2 - Distribution of scientific articles, authors, year, professional, type of intervention and the educational action, 2019

\begin{tabular}{|c|c|c|c|c|c|}
\hline Authors & Year & GRADE $^{(11-12)}$ & Professional & Intervention type & Educational Action \\
\hline $\begin{array}{l}\text { Foshee A. } \\
\text { et al., (13) }\end{array}$ & 1998 & Low & Teachers & $\begin{array}{l}\text { "Interventions with programs } \\
\text { created by authors" }\end{array}$ & Program for the Prevention of Violence in Adolescents. \\
\hline $\begin{array}{l}\text { Fawole Ol. } \\
\text { et al., (15) }\end{array}$ & 2003 & Moderate & $\begin{array}{l}\text { Social } \\
\text { Educators }\end{array}$ & $\begin{array}{l}\text { "Interventions with programs } \\
\text { created by authors" }\end{array}$ & $\begin{array}{l}\text { Lectures, group exercises, presentations, questions and answers, stories, } \\
\text { scenarios and songs. Interactive and participatory sessions with the } \\
\text { public. }\end{array}$ \\
\hline $\begin{array}{l}\text { Runyan W. } \\
\text { et al., (16) }\end{array}$ & 2005 & High & $\begin{array}{l}\text { Social } \\
\text { Educators }\end{array}$ & $\begin{array}{l}\text { "Interventions with programs } \\
\text { created by authors" }\end{array}$ & $\begin{array}{l}\text { PREVENT Model: Preventing Violence Through Education, } \\
\text { Networking, and Technical Assistance }\end{array}$ \\
\hline $\begin{array}{l}\text { Borges, AM. } \\
\text { et al., (17) }\end{array}$ & 2008 & Moderate & $\begin{array}{l}\text { Social } \\
\text { Educators }\end{array}$ & $\begin{array}{l}\text { "Interventions with programs } \\
\text { created by authors" }\end{array}$ & $\begin{array}{l}\text { Educational programs of } 10 \text { to } 15 \text { minutes. A film with a single } \\
\text { presentation and a longer one with presentation and activity. }\end{array}$ \\
\hline $\begin{array}{l}\text { Moynihan M. } \\
\text { et al., (18) }\end{array}$ & 2008 & High & $\begin{array}{l}\text { Social } \\
\text { Educators }\end{array}$ & $\begin{array}{l}\text { "Interventions with standard } \\
\text { programs" }\end{array}$ & $\begin{array}{l}\text { Bystander model modified with the use of a fraternity, sorority and } \\
\text { sports groups of both sexes. }\end{array}$ \\
\hline $\begin{array}{l}\text { Vivolo M. } \\
\text { et al., (19) }\end{array}$ & 2010 & Low & Teachers & $\begin{array}{l}\text { "Interventions with standard } \\
\text { programs" }\end{array}$ & $\begin{array}{l}\text { Community programs and prevention of sexual abuse among } \\
\text { college students. }\end{array}$ \\
\hline $\begin{array}{l}\text { Kraemer M. } \\
\text { et al., (20) }\end{array}$ & 2011 & Moderate & Teachers & $\begin{array}{l}\text { "Interventions with programs } \\
\text { created by authors" }\end{array}$ & $\begin{array}{l}\text { Instruction of didactics, discussion, active behavior skills and role } \\
\text { play, using the sociological prevention model. }\end{array}$ \\
\hline Moor A. ${ }^{(21)}$ & 2011 & High & $\begin{array}{l}\text { Social } \\
\text { Educators }\end{array}$ & $\begin{array}{l}\text { "Interventions with standard } \\
\text { programs" }\end{array}$ & $\begin{array}{l}\text { Workshop of } 2 \text { hours, such as role-playing games, games, role- } \\
\text { plays, film analysis and case studies. }\end{array}$ \\
\hline $\begin{array}{l}\text { Miller E. } \\
\text { et al., (22) }\end{array}$ & 2012 & High & $\begin{array}{l}\text { Social } \\
\text { Educators }\end{array}$ & $\begin{array}{l}\text { "Interventions with standard } \\
\text { programs" }\end{array}$ & $\begin{array}{l}\text { School-based athletic prevention program using the Bystander } \\
\text { model. }\end{array}$ \\
\hline $\begin{array}{l}\text { Espelage L. } \\
\text { et al., }\end{array}$ & 2013 & Low & Teachers & $\begin{array}{l}\text { "Interventions with standard } \\
\text { programs" }\end{array}$ & $\begin{array}{l}\text { Elementary school prevention program is based on the success of } \\
\text { the student's second step. }\end{array}$ \\
\hline $\begin{array}{l}\text { Lundgren R. } \\
\text { et al., (24) }\end{array}$ & 2014 & Moderate & Teachers & $\begin{array}{l}\text { "Interventions with programs } \\
\text { created by authors" }\end{array}$ & Parental interventions for abused children and adolescents. \\
\hline $\begin{array}{l}\text { Sarnquist C. } \\
\text { et al., (25) }\end{array}$ & 2014 & Low & $\begin{array}{l}\text { Social } \\
\text { Educators }\end{array}$ & $\begin{array}{l}\text { "Interventions with programs } \\
\text { created by authors" }\end{array}$ & Training and self-defense. \\
\hline $\begin{array}{l}\text { Bennett S.1 } \\
\text { et al., (26) }\end{array}$ & 2014 & High & $\begin{array}{l}\text { Social } \\
\text { Educators }\end{array}$ & $\begin{array}{l}\text { "Interventions with standard } \\
\text { programs" }\end{array}$ & $\begin{array}{l}\text { Bystander model with measurement of interpersonal variables and } \\
\text { bystander variables. }\end{array}$ \\
\hline $\begin{array}{l}\text { McMahon S. } \\
\text { et al., (27) }\end{array}$ & 2014 & High & $\begin{array}{l}\text { Social } \\
\text { Educators }\end{array}$ & $\begin{array}{l}\text { "Interventions with standard } \\
\text { programs" }\end{array}$ & $\begin{array}{l}\text { Bystander model. Bystander Attitude Scale (BAS-R) and Behavior } \\
\text { Scale (BBS-R). }\end{array}$ \\
\hline $\begin{array}{l}\text { Daigneault I. } \\
\text { et al., (28) }\end{array}$ & 2015 & Moderate & $\begin{array}{l}\text { Social } \\
\text { Educators }\end{array}$ & $\begin{array}{l}\text { "Interventions with standard } \\
\text { programs" }\end{array}$ & Entertaining group discussions. 75 minute workshops. \\
\hline $\begin{array}{l}\text { Sumner A. } \\
\text { et al., (29) }\end{array}$ & 2015 & Moderate & $\begin{array}{l}\text { Parents and } \\
\text { teachers }\end{array}$ & $\begin{array}{l}\text { "Interventions with programs } \\
\text { created by authors" }\end{array}$ & $\begin{array}{l}\text { Five-Step Viewer Model: Observe the event, identify the situation with } \\
\text { the appropriate intervention, take responsibility for the intervention. }\end{array}$ \\
\hline $\begin{array}{l}\text { Mathews C. } \\
\text { et al., (30) }\end{array}$ & 2016 & Low & Researchers & $\begin{array}{l}\text { "Interventions with programs } \\
\text { created by authors" }\end{array}$ & $\begin{array}{l}\text { Intervention with the educational program, school safety and the } \\
\text { school health service. }\end{array}$ \\
\hline $\begin{array}{l}\text { Salazar L. } \\
\text { et al., (31) }\end{array}$ & 2017 & Moderate & Teachers & $\begin{array}{l}\text { "Interventions with standard } \\
\text { programs" }\end{array}$ & $\begin{array}{l}\text { The proposed program, based on theoretical and empirical risk and } \\
\text { protective factors related to sexual violence and perpetration, was } \\
\text { performed in six } 30 \text {-minute modules. }\end{array}$ \\
\hline $\begin{array}{l}\text { Coker AL. } \\
\text { et al., (32) }\end{array}$ & 2017 & High & $\begin{array}{l}\text { Social } \\
\text { Educators }\end{array}$ & $\begin{array}{l}\text { "Interventions with standard } \\
\text { programs" }\end{array}$ & $\begin{array}{l}\text { Green Dot Bystander intervention to reduce sexual violence and related } \\
\text { forms of interpersonal violence in } 26 \text { secondary schools over } 5 \text { years. }\end{array}$ \\
\hline $\begin{array}{l}\text { Reidy DE. } \\
\text { et al., (33) }\end{array}$ & 2017 & Low & Teachers & $\begin{array}{l}\text { "Interventions with programs } \\
\text { created by authors" }\end{array}$ & $\begin{array}{l}\text { Prevention program for young people with previous exposure to } \\
\text { sexual violence. }\end{array}$ \\
\hline $\begin{array}{c}\text { Jessica S., } \\
\text { Kathleen K. }{ }^{(34)}\end{array}$ & 2017 & Low & Teachers & $\begin{array}{l}\text { "Interventions with programs } \\
\text { created by authors" }\end{array}$ & $\begin{array}{l}\text { A multi-level prevention strategy enacts scheduling for students, } \\
\text { teachers, and staff. }\end{array}$ \\
\hline $\begin{array}{l}\text { Ehrensaft M. } \\
\text { et al., (35) }\end{array}$ & 2018 & High & Teachers & $\begin{array}{l}\text { "Interventions with standard } \\
\text { programs" }\end{array}$ & $\begin{array}{l}\text { Prevention program, an adaptation of the incredible years series. } \\
\text { (Webster-Stratton). The program included } 22 \text { weekly 2-hour group } \\
\text { sessions for parents and preschoolers, } 10 \text { biweekly home visits, and up } \\
\text { to six additional family visits over 6-8 month. }\end{array}$ \\
\hline $\begin{array}{l}\text { Andrade E. L. } \\
\text { et al., (36) }\end{array}$ & 2018 & Low & $\begin{array}{l}\text { Social } \\
\text { Educators }\end{array}$ & $\begin{array}{l}\text { "Interventions with standard } \\
\text { programs" }\end{array}$ & $\begin{array}{l}\text { An integral part of the intervention was testing innovative } \\
\text { engagement strategies using digital media. }\end{array}$ \\
\hline
\end{tabular}


English was the language of publication of the articles; the generalization of the language is because most of the studies were carried out in the United States (9 articles) and the journals in which they were published have English as their official language. Other studies were conducted in: France, Canada, Greece, Nairobi, England, Israel, Western Cape, Nigeria and Switzerland.

The analysis full-text concerned educational interventions aimed at preventing violence, through data organized in a brief table and an exhaustive reading of the articles ${ }^{(13)}$.

This review allowed to identify different views of the researchers on the object under study: interventions to prevent sexual violence. Thus, going beyond the methodological aspects of the reviewed articles, we sought to identify the structure of the object under study and we proceeded to sort it into categories according to the type of program applied. For each program, educational techniques, professional, intervention procedure, content, time and place of execution were specified; in some investigations the researchers used more than one strategy $(20,23,25,32,36)$.

Concerning the programs, it should be observed that the review allowed to observe that most of the preventive measures were aimed at adolescents and young adults; this is because it is the stage in which people begin to develop their relationships, while at the same time exposing themselves to large amounts of cultures and misinformation about sexuality and gender ${ }^{(18)}$. Educational programs were developed in colleges and universities, since these are places where adolescents and young people spend most of their time.

\section{DISCUSSION}

Violence, in its different forms, is a problem that encompasses all adolescents, regardless of their age, race and economic situation, among others, so its prevention must focus on the total population. However, certain types of violence are more likely to occur according to age due to the risks present at this stage of life ${ }^{(6-37)}$. To protect this population, the update is essential through the current literature to effectively and accurately meet their need for preventive care.

The review identified different structures of the object studied, classified into two categories "Interventions with programs created by authors" and "Interventions with standard programs".

The first category, "Interventions with programs created by authors" is based on the "ecological model of sensitivity" in which individuals are affected depending on the distance in which they are within the social system. The influence is inversely proportional, systems further away affect the subject to a lesser extent; however, individual predisposition develops subtly and indirectly ${ }^{(14)}$.

Such is the case of PREVENT (Preventing Violence Through Education, Networking, and Technical Assistance) to counteract the influence of systems; educational interventions are created based on pre-established and free pedagogical guides. PREVENT is a tool with the mission of 'improving national professional training systems, leaders and their organizations to prevent violence through effective education, networking and evidence-based technical assistance for the primary prevention of all types of violence ${ }^{\prime(24)}$.

Interventions with self-created programs are aimed at health professionals, community actors, NGOs and service agencies, among others. These entities receive training from 12 professionals in the area of violence, who accompany future trainers through four strategies: face-to-face interaction, networking, distance education, and technical assistance ${ }^{(15-17)}$.

At the end of the interventions with self-created programs, future trainers acquire the necessary skills to identify threats and weaknesses in their social environment, develop educational prevention methods: workshops, training, delivery and explanation of educational materials and interventions for self-care and empowerment. The activities address concepts such as defining a relationship, ways in which relationships may or may not be healthy; power/control dichotomy regarding violence in relationships; sexual abuse/harassment and how it is never the victim's fault; the distinction between unhealthy surprises and appropriate confidences ${ }^{(15-17)}$.

The second category, "Interventions with standard programs" presented programs provided by government entities that already present teaching methodology, intervention steps, strategies for professional training, and thematic content. $99 \%$ of the programs are created in the United States by different health units, such as the Centers for Disease Control and Prevention (CDC) and the National Center for Injury Prevention and Control (NCIPC) ${ }^{(35-36)}$.

The interventions with standard programs are based on the public health model; the foundations of the model are based on the assumption that social and institutional conditions in certain areas contribute to the degradation of social relations, thus fostering cases of violations of the law and violence. To explain this phenomenon, Trajano quotes the theory of broken windows by Kelling and Coles (1996), according to which a neglected environment in which the violation of elementary codes of conduct and respect for heritage and public space is tolerated, results to be a fruitful ground for the increase in violence ${ }^{(31)}$.

Therefore, the target of interventions with standard programs is the circles of social interaction in which people get mixed. Such is the case of the 'Second step-student success through prevention middle school programs'(SS-SSTP) program that is implemented in schools within the students' regular class hours. It is given by previously trained teachers who provide 15 interactive lessons throughout the school year. These lessons have a time-frame of 50 minutes that can be distributed in a single session or two sessions of 25 minutes each. The topics covered collect issues of perpetration of verbal/ physical bullying, mistreatment among peers, physical aggression, victimization and perpetration of homophobic actions, harassment and sexual violence $\mathrm{e}^{(19-23)}$.

On the other hand, the program 'Bystander Interventions' or intervención del espectador in Spanish, which consists of using witnesses of acts of violence as a protection tool; The characteristics and factors that lead one person to "not help" another in a violent situation are shown. The technique consists of applying two scales to assess the attitude --Bystander Attitude Scale-- (BAS-R) and the behavior --Revised and Bystander Behavior Scale-- (BBS-R) of the spectators. They define four important attitudes: high-risk situations, which are attitudes of the bystander about situations where the immediate risk of sexual violence is established to the victim; post-assault situations, which include attitudes about accompanying victims (men or women) to report the facts to the police; post-robbery reporting, which includes reporting the alleged perpetrator and his actions; and finally, proactive opportunities, which involves spectator attitudes about situations in which they cannot cause risks for any one (23-27). 
Actions to prevent sexual violence against adolescents: an integrative literature review Rivera AIV, Mondragón-Sánchez EJ, Vasconcelos FKA, Pinheiro PNC, Ferreira AGN, Galvão MTG.

In the 'Bystander Interventions' program, after the application of the scale, the scores are used for the implementation of empowerment procedures for potential spectators. The main techniques are: in-person --study plans for the development of skills--, workshops of different time-frames are the most researched prevention programs for the training of "potential spectators"; social marketing campaigns; online resources; interactive theater, a strategy to reach large audiences with fewer resources where a group of actors stage events related to sexual assault or violence in relationships and at key moments requests the inclusion or participation of the audience for the positive intervention of the spectators and risk reduction; lastly, teacher training ${ }^{(32-33)}$.

The intervention strategies with standard programs produce a more effective approaching and creation of bonds of trust in low crime areas. As the largest and most consistent impacts of training are on attitudes, including confidence as a spectator and the intention to take action and benefits from the perceived action ${ }^{(34-37)}$.

\section{Limitations of the Study}

The option of checking specific health and nursing databases, specifically in the government entities where the standard interventions were found; this due to the difficulty of access.

\section{Contribution to the Nursing Area}

This study can provide the dissemination of actions to prevent sexual violence in adolescents; prevention actions are the most effective to achieve a healthy and respectable life in the provision of health services at the primary care. Actions aimed at prevention (where health promotion are also included) should fill a preponderant position because they allow increasing the population's health levels. Therefore, the need for more studies focused on the prevention of sexual violence in adolescents is emphasized; in this way, the nurse has tools for their professional practice focused on prevention as the central axis of care and is motivated to carry out interpersonal work.

\section{FINAL CONSIDERATIONS}

The findings in this review reveal the existence of educational actions for the prevention of sexual violence, highlighting that health prevention is in everyone, essential for society's healthy development, which shows that its applicability to the environment favors human health directly.

Health in this area is improved by the prevention of harmful events, supported by educational interventions based on evidence and pedagogical theories. These interventions can be carried out by governments, private organizations and non-governmental organizations. Therefore, they are the largest source of training for people interested in preventive education training. For their part, the different techniques presented in the studies emphasize the student's active role. The duration of these is an important factor since it has been shown that those that techniques last longer are those with better results compared to those of shorter duration.

Similarly, the participants' knowledge was assessed immediately after the intervention, but the evaluation of the acquisition of habits and behavior changes of the participants was lower. It is encouraged to implement interprofessional work for monitoring and, consequently, it is important to confirm the adoption of health prevention attitudes.

\section{REFERENCES}

1. Programa Nacional Contra la Violencia Familiar y Sexual. Informe Estadístico: violencia en cifras [Internet]. Peru: Programa Nacional Contra la Violencia Familiar y Sexual; 2019 [cited 2019 Oct 25]. Available from: https://www.mimp.gob.pe/files/programas_nacionales/pncvfs/ publicaciones/informe-estadistico-01-PNCVFS-UGIGC.pdf

2. Fórum Brasileiro de Segurança Pública (FBSP). Anuário Brasileiro de Segurança Pública [Internet]. São Paulo: FBSP; 2016 [cited 2019 Nov 18]. Available from: https://documentos.mpsc.mp.br/portal/manager/resourcesDB.aspx?path=2229

3. Ferreira RA, Ferriani MGC, de Mello DF, de Carvalho IP, Cano MA, Ferreira RA, et al. Spatial analysis of the social vulnerability of adolescent pregnancy. Cad Saude Publica. 2018;28(2):313-23. doi: 10.1590/S0102-311X2012000200010

4. Sugar NF, Fine DN, Eckert LO. Physical injury after sexual assault: Findings of a large case series. Am J Obstet Gynecol. 2004;190(1):71-6. doi: 10.1016/s0002-9378(03)00912-8

5. Instituto Nacional de Medicina Legal y Ciencias Forenses. Forensis: Datos para la vida 2015 [Internet]. Bogotá: Instituto Nacional de Medicina Legal y Ciencias Forenses; 2015 [cited 2019 Dec 13]. Available from: https://www.medicinalegal.gov.co/documents/20143/49526/Forensis+ 2015.+Datos+para+la+vida.pdf

6. Castillo Saavedra EF, Bernardo Trujillo JV, Medina Reyes MA. Violencia de género y autoestima de mujeres del centro poblado HuanjaHuaraz, 2017. Horiz Med. 2018;18(2):47-52. doi: 10.24265/horizmed.2018.v18n2.08

7. Whittemore R, Knafl K. The integrative review: updated methodology. J Adv Nurs. 2005;52(5):546-53. doi: 10.1111/j.1365-2648.2005.03621.x

8. Elias BL, Polancich S, Jones C, Convoy S. Evolving the PICOT Method for the Digital Age: The PICOT-D. J Nurs Educ. 2015;54(10):594-9. doi:10.3928/01484834-20150916-09

9. Aromataris E, Munn Z (Editors). JBI Manual for Evidence Synthesis. JBI, 2020. Available from https://synthesismanual.jbi.global. https://doi. org/10.46658/JBIMES-20-01

10. Alcântara C, Silva A, Pinheiro P, Queiroz M. Tecnologias digitais para promoção de hábitos alimentares saudáveis dos adolescentes. Rev Bras Enferm. 2019;72(2):537-44. doi: 10.1590/0034-7167-2018-0352. 
Actions to prevent sexual violence against adolescents: an integrative literature review Rivera AIV, Mondragón-Sánchez EJ, Vasconcelos FKA, Pinheiro PNC, Ferreira AGN, Galvão MTG.

11. Ministério da Saúde (BR). Secretaria de Ciência, Tecnologia e Insumos Estratégicos, Departamento de Ciência e Tecnologia. Diretrizes metodológicas: Sistema GRADE - manual de graduação da qualidade da evidência e força de recomendação para tomada de decisão em saúde [Internet]. Brasília; 2014 [cited 2020 Aug 10]. Available from: http://bvsms.saude.gov.br/bvs/ct/PDF/diretriz_do_grade.pdf

12. Guyatt GH, Oxman AD, Kunz R, Atkins D, Brozek J, Vist G, et al. GRADE guidelines: 2. Framing the question and deciding on important outcomes. J Clin Epidemiol. 2011;64(4):395-400.

13. Foshee A, Bauman K, Arriaga B, Helms W, Koch G, Fletcher G. An evaluation of safe dates an adolescent dating violence prevention program. Am J Public Health Res. 1998;88(1):45-50. doi: 10.2105/ajph.88.1.45

14. Higgins ET. Value from hedonic experience and engagement. Psychol Rev. 2006;113(3):439-60. doi: 10.1037/0033-295X.113.3.439

15. Fawole OI, Ajuwon AJ, Osungbade KO, Faweya OC. Interventions for violence prevention among young female hawkers in motor parks in South-Western Nigeria: a review of effectiveness. Afr J Reprod Health. 2003;7(1):71-82. doi: 10.2307/3583347

16. Runyan W, Gunther-Mohr C, Orton C, Umble S, Martin L, Coyne-Beasley T. Prevent a program of the national training initiative on injury and violence prevention. Am J Prev Med. 2005;29(5):252-8. doi: 10.1016/j.amepre.2005.08.013

17. Borges AM, Banyard VL, Moynihan MM. Clarifying consent: primary prevention of sexual assault on a college campus. J Prev Interv Community. 2008;36(1-2):75-88. doi: 10.1080/10852350802022324

18. Moynihan M, Banyard V. Community responsibility for preventing sexual violence: a pilot study with campus geeks and intercollegiate athletes. J Prev Interv Community. 2008;36(1-2):23-38. doi: 10.1080/10852350802022274

19. Vivolo M, Holland A, Teten K, Holt A. Developing sexual violence prevention strategies by bridging spheres of public health. J Women Health. 2010;19(10):1811-14. doi: 10.1089/jwh.2010.2311

20. Kraemer M, Bryan D. A sexual assoult primary prevention model with diverse urban youth. J Child Sex Abus. 2011;20(6):708-27. doi: $10.1080 / 10538712.2011 .622355$

21. Moor A. The efficacy of a high school rape prevention program in Israel. Violence Vict. 2011;26(3):283-95. doi:10.1891/0886-6708.26.3.283

22. Miller E, Tancredi D, McCauley L, Decker M, Virata MC, Anderson HA, et al. “Coaching Boys into Men”: a cluster-randomized controlled trial of a dating violence prevention-program. J Adolesc Health Care.2012; 51(5):431-38. doi: 10.1016/j.jadohealth.2012.01.018

23. Espelage L, Low D, Polanin S, Brownd C. The impact of a middle school Program to reduce aggression, victimization, and sexual violence. J Adolesc Health Care. 2013;53(2):180-86. doi: 10.1016/j.jadohealth.2013.02.021

24. Lundgren $\mathrm{R}$, Amin A. Addressing intimate partner violence and sexual violence among adolescents: emerging evidence of effectiveness. J Adolesc Health Care. 2015;56(1):S42-S50. doi: 10.1016/j.jadohealth.2014.08.012

25. Sarnquist C, Omondi B, Sinclair J, Gitau C, Paiva L, Mulinge M, et al. Rape prevention through empowerment of adolescent girls. Pediatrics. 2014;133(5):e1226-32. doi: 10.1542/peds.2013-3414

26. Bennett S, Banyard L. To act or not to act, that is the question? barriers and facilitators of by stander intervention. J Interpers Violence. 2014;29(3):476-96. doi: 10.1177/0886260513505210

27. McMahon S, Allen CT, Postmus JL, McMahon SM, Peterson NA, Lowe Hoffman M. Measuring bystander attitudes and behavior to prevent sexual violence. J Am Coll Health. 2014;62(1):58-66. doi: 10.1080/07448481.2013.849258

28. Daigneault I, Martine H, McDuff P, Michaud F, Vézina-Gagnon P, Henry A, et al. Effectiveness of a sexual assault awareness and prevention workshop for youth: a 3-month follow-up pragmatic cluster randomization study. Can J Hum Sex. 2015;24(1):19-30. doi: 10.3138/cjhs.2626

29. Sumner A, Mercy A, Dahlberg L, Hillis D, Klevens S, Houry D. Violence in the United States: status, challenges, and opportunities. JAMA. 2015;314(5):478-88. doi: 10.1001/jama.2015.8371

30. Mathews C, Eggers M, Townsend S, Aaro LE, De Vries PJ, Mason-Jones AJ, et al. Effects of PREPARE, a multi-component, school-based HIV and intimate partner violence (IPV) prevention programme on adolescent sexual risk behaviour and IPV: cluster randomised controlled trial. AIDS Behavior. 2016;20(9):1821-40. doi: 10.1007/s10461-016-1410-1

31. Laura FS, Alana VK, Kira McGK. Formative research with college men to inform content and messages for a web-based sexual violence prevention program. Health Communic. 2017;32(9):1133-41. doi: 10.1080/10410236.2016.1214219

32. Coker AL, Bush HM, Cook-Craig P, DeGue SA, Clear ER, Brancato CJ, et al. RCT testing bystander effectiveness to reduce violence. Am J Prev Med. 2017;52(5):566-78. doi: 10.1016/j.amepre.2017.01.020

33. Reidy DE, Holland KM, Cortina K, Barbara B, Barri R. Evaluation of the expect respect support group program: a violence prevention strategy for youth exposed to violence. Prev Med 2017;100:235-42. doi: 10.1016/j.ypmed.2017.05.003

34. Jessica S, Kathleen K. Schools must include faculty and staff in sexual violence prevention efforts. J Am College Health. 2017;65(8):585-87. doi:10.1080/07448481.2017.1349133

35. Ehrensaft M, Westfall H, Niolon PH, Lopez T, Kamboukos D, Huang KY, et al. Can a parenting intervention to prevent early conduct problems interrupt girls' risk for intimate partner violence 10 years later? Prev Sci. 2018;19(4):449-58. doi: 10.1007/s11121-017-0831-z

36. Andrade EL, Evans WD, Barrett ND, Cleary SD, Edberg MC, Alvayero RD, et al. Development of the place-based Adelante social marketing campaign for prevention of substance use, sexual risk and violence among Latino immigrant youth. Health Education Research. 2018; 33(2):125-44. doi: 10.1093/her/cyx076

37. Sento-se JT. Prevenção ao crime e teoria social. Lua Nova. 2011;83: 9-40. doi: 10.1590/S0102-64452011000200002 